\title{
A correlation of haloperidol-induced cognitive deficit with dysfunctional dopamine receptor activity in nonhuman primate
}

This article was published in the following Dove Press journal:

Open Access Animal Physiology

3 May 2010

Number of times this article has been viewed

\author{
Irene Navarro-Lobato',2 \\ Mariam Masmudi-Martín' \\ Manuel F López-Aranda',2,3 \\ Juan Félix López-Téllez, ${ }^{1,3}$ \\ Zafar U Khan ${ }^{1,2,3}$ \\ 'Laboratory of Neurobiology at \\ CIMES, Department of Medicine, \\ Faculty of Medicine, University of \\ Málaga, Málaga, Spain; ${ }^{2}$ Department \\ of Medicine, Faculty of Medicine, \\ University of Málaga, Málaga, Spain; \\ ${ }^{3}$ CIBERNED, Institute of Health \\ Carlos III, Madrid, Spain
}

\begin{abstract}
Haloperidol is an antipsychotic drug that acts through blockage of dopamine $\mathrm{D}_{2}$ receptors. Chronic administration of this antipsychotic drug in nonhuman primates induces a pronounced cognitive deficit. However, receptor subtypes that are responsible for this cognitive dysfunction remain unknown. Therefore, brains of chronic haloperidol-treated young and aged monkeys were used to analyze the intricate relation of receptor activity, cognitive dysfunction, and haloperidol-mediated actions in the production of harmful effects. Taking into account the significant cognitive loss observed after haloperidol treatment, it was predicted that changes in the cognitive status that correlate with the receptor activity in the prefrontal cortex and striatum, areas implicated in the processing of haloperidol-mediated effects in brain, should be common in both young and aged animals. Based on this concept, we observed that in the prefrontal cortex, dopamine $\mathrm{D}_{1}$ and $\mathrm{D}_{2}$ receptors showed changes in receptor levels that were common in both age groups. However, this relationship was absent in $\mathrm{GABA}_{\mathrm{A}}$, serotonin 5HT2 and muscaranic receptors. In contrast to the prefrontal cortex, in striatum, this change was restricted to the dopamine $\mathrm{D}_{2}$ receptors only. Therefore, from our results, it seems that apart from the downregulation of $\mathrm{D}_{1}$ receptor activity in the prefrontal cortex, an upregulation of $\mathrm{D}_{2}$ receptors could also contribute to the generation of the cognitive loss observed in haloperidol-treated monkeys. Additionally, reduced excitatory input due to hampered cortico-striatal $\mathrm{D}_{1}$ dopaminergic activity and stronger inhibition at the synapse of excitatory input site by upregulated striatal $\mathrm{D}_{2}$ receptor activity could promote the side effects associated with haloperidol.
\end{abstract}

Keywords: cognitive deficit, nonhuman primates, haloperidol, antipsychotic drug, receptor activity

\section{Introduction}

Schizophrenia is a disease that, in addition to cognitive dysfunction, is composed of negative ${ }^{1,2}$ and psychotic symptoms. ${ }^{3}$ Current knowledge on the neurochemistry underlying the pathogenesis of schizophrenia implies alterations in neurotransmitter systems such as dopamine, glutamate, and serotonin. ${ }^{4}$ Chronic antipsychotic drug administration is a crucial component in the current treatment of schizophrenia. Conventional or typical antipsychotic drugs, such as haloperidol, reverse psychotic symptoms, but are not particularly effective against negative symptoms or cognitive deficits. Since positive symptoms of schizophrenia are suggested to arise from hyperdopaminergic activity, especially from the over-activation of dopamine $\mathrm{D}_{2}$ receptors, typical antipsychotic drugs release their therapeutic properties mainly by blocking these receptors. This $\mathrm{D}_{2}$ receptor blockade is accompanied by disturbing and incapacitating side effects, so-called extrapyramidal symptoms, including
Lab. Neurobiología, CIMES, Universidad de Málaga, Campus Teatinos,

2907I-Málaga, Spain

$\mathrm{Tel}+34952$ I3 7279

Fax +34952 137270

Email zkhan@uma.es 
a parkinsonism-like syndrome and tardive dyskinesia., 5 More than $70 \%$ of schizophrenia patients treated with typical antipsychotic drugs discontinue their medication within 18 months because of the side effects accompanying their drug treatment. ${ }^{7}$ Haloperidol is a potent $\mathrm{D}_{2}$ antagonist that exhibits low activity at 5-HT2 A, $\mathrm{D}_{1}$, and adrenergic receptors, and has only minimal affinity to 5-HT1A and histamine (H1) receptors. ${ }^{8}$ Animal studies have demonstrated that prolonged treatment with typical antipsychotics not only produces cognitive abnormality, but also induces purposeless chewing behavior ${ }^{9-11}$ and orofacial movements that are thought to result from potent $\mathrm{D}_{2}$ blockade and a disruption of the balance between the $\mathrm{D}_{1}$ and $\mathrm{D}_{2}$ receptors. ${ }^{12-14}$

The cortico-striatal pathway is involved in cognitive processing including the selection and execution of action. ${ }^{15,16}$ The striatum receives excitatory input from the cerebral cortex and thalamus and dopaminergic innervation from the midbrain. Dopaminergic activity modulates the flow of information through the striatum and the plasticity of corticostriatal synapses. It is thought that dopaminergic activity in the cortico-striatal pathway plays an important role in not only haloperidol-mediated antipsychotic activity, but also undesirable side effects.

Schizophrenics have been shown to exhibit abnormal activities in the prefrontal cortex, ${ }^{17-19}$ but a blockade of up to $80 \%$ of $\mathrm{D}_{2}$ receptors in the striatum is required for the antipsychotic effect to take place in these patients. ${ }^{6}$ However, it has been suggested that mechanisms that interfere with the dopaminergic, noradrenergic, and cholinergic activity in the prefrontal cortex might be responsible for both the beneficial and negative side effects related to haloperidol treatment in schizophrenics.

The prefrontal dysfunction has been shown to have the greatest effect on cognitive behavior. ${ }^{3}$ Findings of the induction of cognitive impairments after chronic haloperidol administration to young adult monkeys, and the reversal of this loss by activation of dopamine $\mathrm{D}_{1}$ receptors, ${ }^{20}$ suggest a direct implication of dopaminergic neurotransmission in the processing of cognitive function. Haloperidol is thought to exert its therapeutic effects through dopamine $\mathrm{D}_{2}$ receptor blockade because of its strong correlation between clinical efficacy and affinity for dopamine $\mathrm{D}_{2}$ receptors. ${ }^{21}$ However, delay in therapeutic efficacy of haloperidol, like other neuroleptics, is puzzling. Haloperidol-mediated dopamine $\mathrm{D}_{2}$ receptor blockade occurs within hours but antipsychotic effects take several days or weeks to develop. ${ }^{22-25}$ Activation of the extracellular signal-regulated kinase (ERK) pathway and immediate early genes in response to haloperidol treatment, ${ }^{26,27}$ suggests participation of protein synthesis machinery in this process. Changes in the protein level of specific receptor types may contribute to delayed therapeutic efficacy of haloperidol because drug-mediated modulation in protein synthesis is expected to happen much later than the $\mathrm{D}_{2}$ receptor blockade.

Here, we have tested the theory of whether there is an imbalance in receptor neurotransmission due to a change in receptor levels and its correlation with the cognitive status in brains of young and aged nonhuman primates chronically treated with haloperidol. Both the striatum and prefrontal cortex areas of the brain of the haloperidol-treated animals with significant cognitive loss were processed for the determination of levels of various receptors associated to G-protein signaling and ion channels. Our results show that there was selective abnormality in dopaminergic receptor function in both areas that correlated with the cognitive profiles of both young and aged group of monkeys.

\section{Materials and methods Materials}

Radioligands $\left[{ }^{3} \mathrm{H}\right] \mathrm{SCH}$ 23390, $\left[{ }^{3} \mathrm{H}\right]$ Raclopride, $\left[{ }^{3} \mathrm{H}\right]$ Flunitrazepam, $\left[{ }^{3} \mathrm{H}\right]$ Scopolamine, and $\left[{ }^{3} \mathrm{H}\right]$ Ketanserin were purchased from PerkinElmer España SL (Madrid, Spain). The haloperidol (powder form) and antagonists (+) butaclamol-HCl, fluphenazine, benzodiazepine, LY 53857, and metoclopromide were from Sigma-RBI (Madrid, Spain).

\section{Subjects}

Nine young Rhesus monkeys aged 5-7 years and eight monkeys aged 18-22 years were used in this study. Animals were maintained in accordance with the guidelines of local Animal Experimentation, Welfare and Protection Committee and European Union Law (Council directive 86/609/EEC adopted in 1986 and the Protocol to the Amsterdam Treaty).

All monkeys were trained on spatial working memory tasks using the Wisconsin General Testing Apparatus (WGTA) according to methods described elsewhere. ${ }^{28}$ Animals performing tasks with $75 \%-85 \%$ accuracy (in case of young animals) and $65 \%-70 \%$ accuracy (in case of old animals), with a 5 -second delay period were used for the treatments and further studies.

\section{Cognitive behavioral test}

Performance on a spatial delayed response task ${ }^{20}$ was used to assess the working memory (WM) status of all the animals 
in this study. To execute the spatial delayed response task, one of the two food wells in WGTA was baited in the view of monkey, then both wells were covered with identical plaques and an opaque screen was lowered for 5 seconds. During the delay period, the monkey must hold in mind the spatial location of the baited well to respond appropriately and be rewarded. After the delay, the animal has to move the correct plaque to obtain the reward. Animals were required to perform 30 trials per test session and cognitive statuses were determined from the mean of 90 trials for each group. These values were used to calculate percentage of correct choice for each as shown in Figure 1.

\section{Haloperidol treatment and cognitive status}

Haloperidol treatment in nonhuman primates was performed with the use of a technique from previously published articles. ${ }^{20,29}$ Animals that showed significant reduction in performance on the spatial delayed response task after treatment with haloperidol were considered cognitively-deficient.

Five young monkeys were administered daily with a powder form of haloperidol, disguised in fruit, at a dose of $0.07 \mathrm{mg} / \mathrm{kg}$ body weight during the first month, which was increased to $0.14 \mathrm{mg} / \mathrm{kg}$ body weight in the second month. The cognitive status of these monkeys was monitored by observing the animal performance on the delayed response task as described above. ${ }^{20}$ Haloperidol-mediated cognitive deficits emerged between three and four months in all young monkeys. Animals were sacrificed after four months of the initiation of drug treatment, a period sufficient for substantial WM loss to be observed.

In another set of four aged monkeys, haloperidol treatment was initiated by administration of daily doses of $0.20 \mathrm{mg} / \mathrm{kg}$ body weight, increased to 0.27 , and $0.35 \mathrm{mg} / \mathrm{kg}$ body weight at two-week intervals. The latter dose was maintained until the time of sacrifice. Once the cognitive deficit was observed, animals were sacrificed. Four of each young and aged control group monkeys were given fruit only.

\section{Tissue collection}

Monkeys were anesthetized with ketamine and atropine for restraint and then euthanized with an overdose of sodium pentobarbital. They were perfused transcardially with Ringer's solution, followed by immediate removal of the brain. The brains were rapidly dissected on ice into small blocks of dorsolateral prefrontal cortex (area 46) and striatum (caudateputamen), frozen in liquid $\mathrm{N}_{2}$, and stored at $-80^{\circ} \mathrm{C}$.

\section{Membranes preparation}

Collected brain tissues were homogenized in Tris-HCl, $\mathrm{pH} 7.4$ containing a cocktail of protease inhibitors (Sigma-Aldrich, St. Con's, MO) and processed for membrane preparation as described in earlier studies. ${ }^{30-32}$ Briefly, homogenates were centrifuged at $3000 \mathrm{rpm}(1075 \mathrm{~g})$ for $10 \mathrm{~min}$ in a
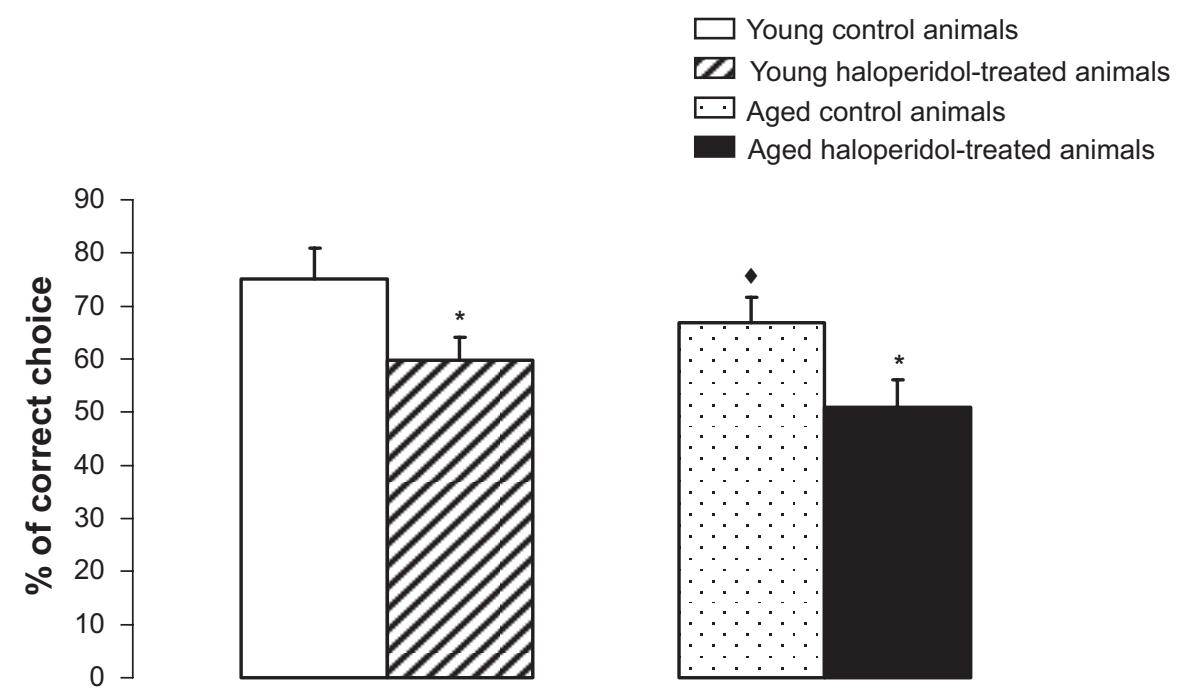

Figure I Cognitive status of monkeys prior to sacrifice.

Notes: Similar to results of previous studies, ${ }^{20}$ haloperidol treatment of both young (hatched bar) and aged (black bar) groups of animals produced profound loss in their performance on a cognitive task. In addition, nontreated aged animals (dotted bar), showed significant cognitive decline when compared to the control group of nontreated young animals (white bar). *Indicates results that are significantly different from their control group. "Indicates results that are significantly different from the young animal control group. 
RC5C centrifuge (Sorvall, Foster city, CA). The resultant supernatant was centrifuged at 48, $100 \mathrm{rpm}(105,000 \mathrm{~g})$ for $1 \mathrm{~h}$ in XL-90 Ultracentrifuge (Beckman, Fullerton, CA) to collect the membrane fraction as a pellet. Membrane fractions were washed twice in $50 \mathrm{mM}$ Tris- $\mathrm{HCl}, \mathrm{pH} 7.4$ and finally suspended in the same buffer and aliquoted. Aliquots were stored at $-80^{\circ} \mathrm{C}$ until used. The protein concentration was determined by the Lowry method.

\section{Receptor binding}

For the determination of active receptor concentration in both the prefrontal cortex and striatal membranes, receptor-specific radioligand binding assay was performed. ${ }^{31,33} \mathrm{H}-\mathrm{SCH} 23390$ was used for the estimation of dopamine $\mathrm{D}_{1}$ receptor, ${ }^{3} \mathrm{H}$-Raclopride for dopamine $\mathrm{D}_{2}$ receptor, ${ }^{3} \mathrm{H}$-Flunitrazepam for $\mathrm{GABA}_{\mathrm{A}}$ receptor, ${ }^{3} \mathrm{H}$-Scopolamine for acetylcholine muscaranic receptor, and ${ }^{3} \mathrm{H}$-Ketanserin for serotonin $5-\mathrm{HT}_{2}$ receptor. For the assay, $200 \mu \mathrm{g}$ of membrane protein was incubated with $0-20 \mathrm{nM}$ of radioligand for 1 hour at $22^{\circ} \mathrm{C}$ in a total volume of $0.5 \mathrm{~mL}$ of $50 \mathrm{mM}$ Tris- $\mathrm{HCl}(\mathrm{pH} \mathrm{7.4)}$ containing $1 \mathrm{mM}$ EDTA, $5 \mathrm{mM} \mathrm{KCl}, 1.5 \mathrm{mM} \mathrm{CaCl}_{2}$, $4 \mathrm{mM} \mathrm{MgCl}_{2}$, and $120 \mathrm{mM} \mathrm{NaCl}$. The reaction was stopped by rapid filtration through $0.3 \%$ polyethylenimine-soaked (GF/B filters; Whatman, Flurham Park, NJ) and washed three times with $50 \mathrm{mM}$ Tris- $\mathrm{HCl}, \mathrm{pH}$ 7.4. The filters were dried and counted for retained radioactivity. Nonspecific binding was determined by performing the assay in the presence of 1000x of either $(+)$ butaclamol-HCl or fluphenazine for both dopamine receptors, benzodiazepine for $\mathrm{GABA}_{\mathrm{A}}$ receptor, LY 53857 for serotonin 5- $\mathrm{HT}_{2}$ receptor, and metoclopromide for muscaranic receptor. Background activity was subtracted from total activity, which was 5\%-7\%.

\section{Data analysis}

Values are presented as mean \pm standard error of mean (SEM) of 4-5 animals in each group. Statistical analysis of the physiologic variables was performed using Student's $t$-test. A probability value less than 0.05 was considered statistically significant.

\section{Results}

Though WM loss due to haloperidol treatment has previously been demonstrated, ${ }^{20}$ our idea of a behavioral test in the current study was not only to confirm this observation, but also to use it as a strategy for teasing out the relationship between cognitive deficit and receptor function, together with the prefrontal cortex and striatum, areas known to manifest haloperidol-mediated activity. Additionally, inclusion of both young and aged monkey in our study has added further to our understanding of this relationship. We found that response to haloperidol treatment seen at the receptor level in young animals was much different than in aged animals. However, both young and aged groups of animals showed a significant cognitive loss to the treatment of haloperidol, thus its effect was common to both ages (Figure 1). Receptors contributing to the cognitive change may also be common in both ages.

The results from the ligand binding based estimation of active receptor concentration suggest that chronic haloperidol treatment to both adult and aged monkeys produces significant alterations in receptor-mediated intracellular signaling processes in the striatum and prefrontal cortex. These areas of brain are known to be linked to the antipsychotic effects of haloperidol. In general, the effect of haloperidol treatment in aged monkeys was restricted to dopamine receptors. In the young group of animals, however, the effect was spread to many receptors. We have observed that in the prefrontal cortex, dopamine $\mathrm{D}_{1}$ receptor level was reduced by $32.8 \% \pm 1.6 \%$ in young monkeys and $28.4 \% \pm 2.4 \%$ in aged monkeys after receiving the treatment with haloperidol (Figure 2A). However, in contrast to dopamine $\mathrm{D}_{1}$ receptors, haloperidol treatment induced increase in dopamine $\mathrm{D}_{2}$ receptor levels (Figure $2 \mathrm{~B}$ ). The haloperidol-mediated increase in $\mathrm{D}_{2}$ receptor was $33.1 \% \pm$ $3.1 \%$ in young monkeys and $31.5 \% \pm 3.9 \%$ in aged monkeys (Figure 2B). In the same area, there was a marginal increase in $\mathrm{GABA}_{\mathrm{A}}$ receptor levels (Figure 2C), and no effect in muscaranic receptors (Figure 2E), but a robust decrease $(37.6 \% \pm 4.1 \%)$ in serotonin $5 \mathrm{HT}_{2}$ receptors (Figure 2D) was observed in haloperidol-treated young animals. Aged monkeys showed no effect in $\mathrm{GABA}_{\mathrm{A}}$ (Figure 2C), serotonin $5 \mathrm{HT}_{2}$ (Figure 2D), or muscaranic (Figure 2E) receptors after the treatment with haloperidol. With the consideration of cognitive changes seen in the same animals, we observed that in prefrontal cortex, the effect of haloperidol treatment in both young and aged group of animals was confined more to dopamine $\mathrm{D}_{1}$ and $\mathrm{D}_{2}$ receptors (Figure 2).

Dissimilar to the prefrontal cortex, haloperidol treatment produced a distinct profile in the striatum (Figure 3 ). In both groups of animals, haloperidol-mediated effect was mostly related to dopamine $\mathrm{D}_{2}$ receptors only and not to both dopamine $\mathrm{D}_{1}$ and $\mathrm{D}_{2}$ receptors, as was in case of prefrontal cortex. Though no effect of haloperidol treatment on striatal $\mathrm{D}_{1}$ receptors was observed (Figure $3 \mathrm{~A}$ ), we found a robust increase in $\mathrm{D}_{2}$ receptors of young $(28.7 \% \pm 3.1 \%)$ and aged $(21.2 \% \pm 1.6 \%)$ monkeys (Figure 3B). Haloperidol drastically reduced striatal $\mathrm{GABA}_{\mathrm{A}}$ receptor $(39.6 \% \pm$ 


\section{A Dopamine $D_{1}$ receptor}
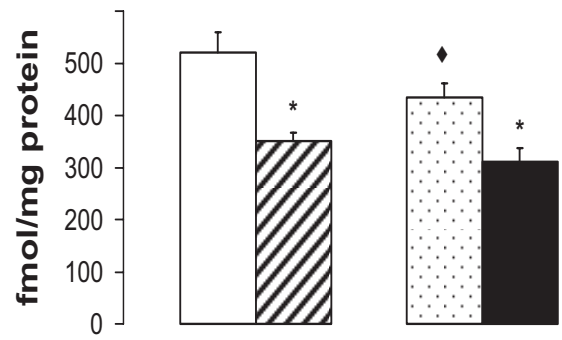

B Dopamine $D_{2}$ receptor

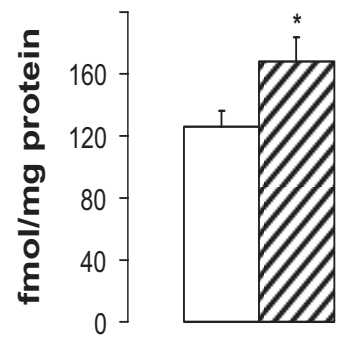

C GABA $_{\mathrm{A}}$ receptor
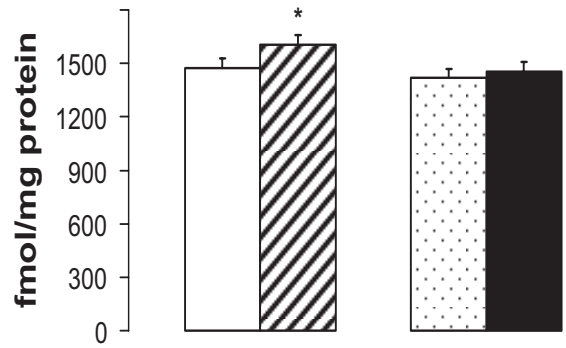

D Serotonin $5 \mathrm{HT}_{2}$ receptor

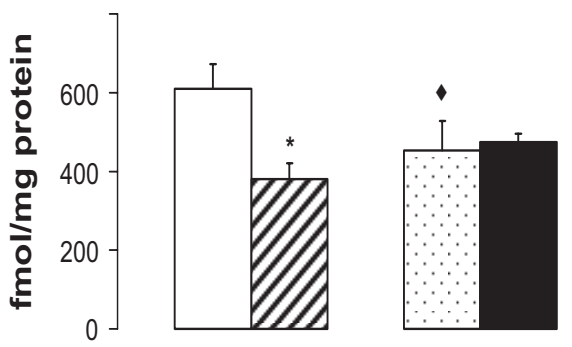

Young control animals

ZZ Young haloperidol-treated animals

$\because$ Aged control animals

Aged haloperidol-treated animals

E Acetylcholine muscarinic receptor

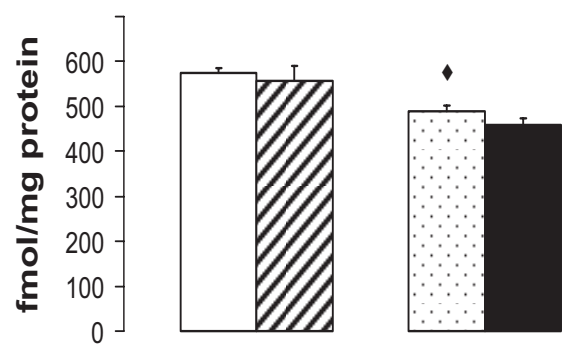

Figure 2 Receptor levels in prefrontal cortex of animals treated with haloperidol.

Notes: Though the response of young animals to haloperidol treatment was observed in many of the receptors tested, only dopamine $\mathrm{D}_{1}\left(\right.$ Figure $2 \mathrm{~A}$ ) and $\mathrm{D}_{2}$ (Figure $2 \mathrm{~B}$ ) receptors showed changes in animals of both age groups that correlated well to the cognitive profile (Figure I) of these monkeys. *Indicates results that are significantly different from their control group. •Indicates results that are significantly different from the young animal control group.

$2.0 \%$ ) (Figure 3C), serotonin $5 \mathrm{HT}_{2}$ receptor $(30.3 \% \pm 1.2 \%)$

(Figure 3D), and muscaranic receptor $(55.1 \% \pm 5.2 \%)$

(Figure 3E) levels in young animals, but no change was observed in these receptors in aged animals.

With respect to the effect of aging on these receptors, we found a decreasing trend in aged monkeys with the exception of $\mathrm{GABA}_{\mathrm{A}}$ receptors, where no significant change was observed in both areas of brain (Figures 2 and 3). In the prefrontal cortex and striatum, there was a decline of $14 \%-16 \%$ in dopamine $\mathrm{D}_{1}$ receptors, whereas, the reduction in dopamine $\mathrm{D}_{2}$ receptors was $23.6 \% \pm 2.4 \%$ and $17.1 \% \pm 2.6 \%$, respectively. A noticeable decrease of $25.6 \% \pm 4.2 \%$ in serotonin $5 \mathrm{HT}_{2}$ receptor was observed in the prefrontal cortex as compared to $17.9 \% \pm 1.2 \%$ in the striatum. Prefrontal cortical $\mathrm{D}_{2}$ receptors and serotonin $5 \mathrm{HT}_{2}$ receptors seem to be profoundly affected by aging. The most striking observation in the aged group of monkeys was that haloperidol treatment was restricted to the dopamine receptors.

\section{Discussion}

WM deficits have been proposed as a stable marker for the illness of schizophrenia since they have been described as one of the most consistently observed symptoms in schizophrenic patients. ${ }^{34}$ Ongoing antipsychotic drug administration is a critical component of the current remedy for schizophrenia. We, as well as others, have observed that chronic haloperidol administration induces WM deficit in both young and aged monkeys. ${ }^{20,29}$ It has been shown that this cognitive func- 
A Dopamine $D_{1}$ receptor
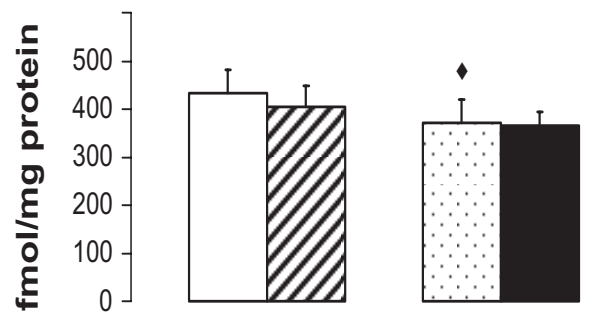

C GABA $_{\mathrm{A}}$ receptor
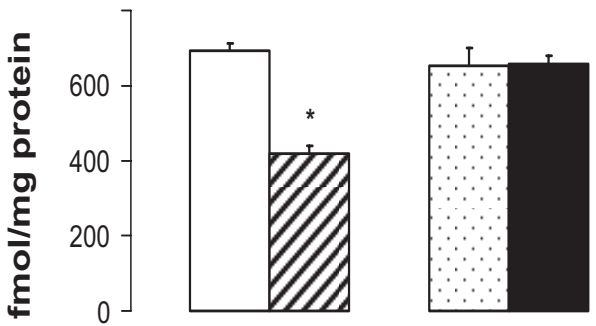

D Serotonin $5 \mathrm{HT}_{2}$ receptor
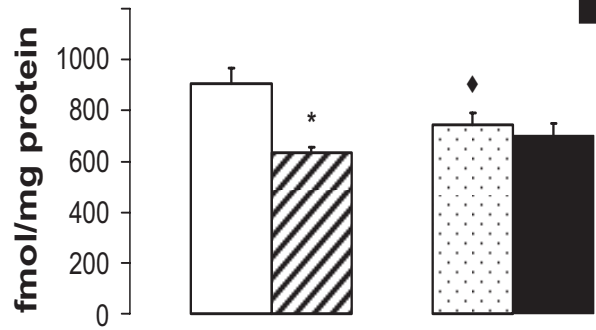

Young control animals

Z Young haloperidol-treated animals

$\because$ Aged control animals

Aged haloperidol-treated animals

E Acetylcholine muscarinic receptor

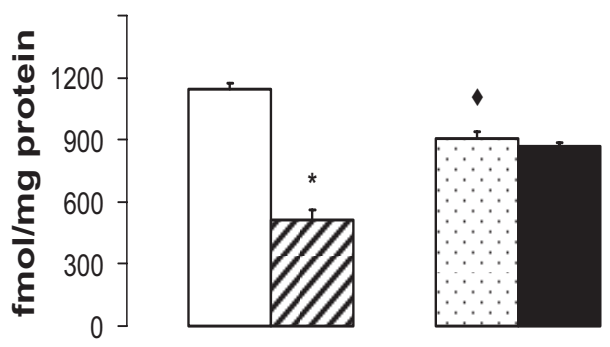

Figure 3 Receptor levels in the striatum of animals treated with haloperidol.

Notes: In contrast to the prefrontal cortex, the effect of haloperidol treatment on the striatum was associated with dopamine $D_{2}$ receptors (Figure $3 B$ ) and not the $D_{1}$ receptors (Figure 3A) in animals of both age groups. However, only in the young group of animals was a considerable change observed in the other receptors tested. *Indicates results that are significantly different from their control group. 'Indicates results that are significantly different from the young animal control group.

tion is dependent on intact prefrontal systems $\mathrm{s}^{35,36}$ and that dysfunction in prefrontal cortex causes schizophrenia. ${ }^{17-19}$ Our results of a correlation between cognitive dysfunction and abnormality in the function of dopamine receptors in haloperidol-treated monkeys suggest that dopamine receptor activity may play an important role in cognitive processing and that it may be a key to the schizophrenia. Particularly, in the prefrontal cortex, haloperidol-mediated loss in prefrontal dopamine $\mathrm{D}_{1}$ receptors in animals of both age groups coincides well with their cognitive profiles. This is supported by the observation that haloperidol-induced cognitive loss could be reversed by the activation of dopamine $\mathrm{D}_{1}$ receptors. ${ }^{20}$ Thus, it has been suggested that the downregulation of cortical $\mathrm{D}_{1}$ receptors may be a component of response to haloperidol treatment in the prefrontal cortex. Based on our results, however, it is argued that not only is a decrease in dopamine $\mathrm{D}_{1}$ receptors, but also upregulation in dopamine $\mathrm{D}_{2}$ receptors in the prefrontal cortex crucial for haloperidol-induced antipsychotic activity. In concurrence with this, over-activity of $\mathrm{D}_{2}$ receptor signaling is known to be psychotomimetic, and blocking this receptor plays a key therapeutic role in diminishing positive symptoms in schizophrenia. ${ }^{21,37}$

In addition to the selective activities in the dopamine receptor system of the prefrontal cortex, dopamine $\mathrm{D}_{2}$ receptor antagonism of antipsychotic drugs and their ability to upregulate striatal $\mathrm{D}_{2}$ receptors is considered one of the cornerstones of the dopaminergic hypothesis of schizophrenia. ${ }^{38-42}$ The observation that antipsychotics bind to and block striatal dopamine $\mathrm{D}_{2}$-like receptors in direct correlation with their clinically effective antipsychotic doses ${ }^{21,37}$ suggests that striatal dopaminergic systems play a major role in schizophrenia. 
A number of animal studies report an upregulation of striatal $\mathrm{D}_{2}$-like receptors after subchronic short-term drug administration, ${ }^{43-45}$ the period during which beneficial clinical effects of antipsychotics on human patients are first noticed. The classic or 'typical' antipsychotics, including haloperidol, although effective for blocking psychoses, also cause extrapyramidal movement disorders, both transient (eg, parkinsonism, dystonia, akathisia) and chronic (eg, tardive dyskinesia, TD). ${ }^{46,47}$ Atypical antipsychotic drugs, the prototype of which is clozapine, have been developed that are devoid of these extrapyramidal side effects. Short treatment periods of rats with clozapine has been reported not to increase striatal $\mathrm{D}_{2}$-like receptor levels. ${ }^{45,48}$ This suggests that the upregulation of striatal $\mathrm{D}_{2}$-like receptors is more likely associated with drug-induced extrapyramidal motor side effects rather than mediation of their antipsychotic action.

In addition, never-medicated subjects with schizophrenia sometimes exhibit motor deficits resembling those of patients with primary striatal dysfunction, ${ }^{49,50}$ and clinical improvement of schizophrenic symptoms treated with neuroleptics has been found to be associated with increased basal ganglia metabolism, possibly reflecting neuroadaptation processes in the striatum. ${ }^{51,52}$ It has been shown that chronic, but not acute haloperidol treatment facilitates the emergence of long-term potentiation (LTP) versus long-term depression (LTD) at cortico-striatal excitatory synapses. The $\mathrm{D}_{2} \mathrm{~L}$ isoform of $\mathrm{D}_{2}$ receptors is responsible for the facilitatory action of classical antipsychotics on excitatory transmission in the striatum. It is known that cortical excitatory information is converged to the striatum at a constant pace, where it modulates local cellular activity. Considering our observation of downregulation of dopamine $\mathrm{D}_{1}$ receptor activity and inhibition of glutamate N-methyl D-aspartate (NMDA) receptor function due to upregulation in $\mathrm{D}_{2}$ receptor in prefrontal cortex, it is suggested that not only $\mathrm{D}_{1}$-mediated but also NMDA-mediated excitatory input in the striatum is significantly reduced in these animals, causing an overall striatal dysfunction. Therefore, in addition to the higher dopamine $\mathrm{D}_{2}$ receptor activity in the striatum that is expected to promote stronger inhibition at the excitatory input site, it is likely that an aberration in dopamine receptor-mediated excitatory input to the striatum plays a fundamental role in the development of extrapyramidal side effects.

\section{Disclosures}

The authors report no conflicts of interest in this work. This work was supported financially by Ministerio de Ciencia e
Innovacion grant BFU 06-0306 and a Junta de Andalucia grant CTS 586/08 to Z.U.K.

\section{References}

1. Carter C, Robertson L, Nordahl T, Chaderjian M, Kraft L, O'Shora-Celaya L. Spatial working memory deficits and their relationship to negative symptoms in unmedicated schizophrenia patients. Biol Psychiatry. 1996;40(9):930-932.

2. Park S, Puschel J, Sauter BH, Rentsch M, Hell D. Spatial working memory deficits and clinical symptoms in schizophrenia: a 4-month follow-up study. Biol Psychiatry. 1999;46(3):392-400.

3. Weinberger DR, Aloia MS, Goldberg TE, Berman KF. The frontal lobes and schizophrenia. J Neuropsychiatry Clin Neurosci. 1994;6(4):419-427.

4. Wong AH, Van Tol HH. Schizophrenia: from phenomenology to neurobiology. Neurosci Biobehav Rev. 2003;27(3):269-306.

5. McEvoy JP. The clinical use of anticholinergic drugs as treatment for extrapyramidal side effects of neuroleptic drugs. J Clin Psychopharmacol. 1983;3(5):288-302.

6. Wadenberg ML, Kapur S, Soliman A, Jones C, Vaccarino F. Dopamine $\mathrm{D}_{2}$ receptor occupancy predicts catalepsy and the suppression of conditioned avoidance response behavior in rats. Psychopharmacology (Berl). 2000;150(4):422-429.

7. Lieberman JA, Stroup TS, McEvoy JP, et al. Effectiveness of antipsychotic drugs in patients with chronic schizophrenia. $N$ Engl $J$ Med. 2005;353(12):1209-1223.

8. Goldstein JM. The new generation of antipsychotic drugs: how atypical are they? Int J Neuropsychopharmacol. 2000;3(4):339-349.

9. Andreassen OA, Jorgensen HA. The rat model of tardive dyskinesia: relationship between vacuous chewing movements and gross motor activity during acute and long-term haloperidol treatment. Life Sci. 1995;57(24):2263-2272.

10. Egan MF, Hurd Y, Ferguson J, Bachus SE, Hamid EH, Hyde TM. Pharmacological and neurochemical differences between acute and tardive vacuous chewing movements induced by haloperidol. Psychopharmacology (Berl). 1996;127(4):337-345.

11. Trevitt JT, Lyons M, Aberman J, Carriero D, Finn M, Salamone JD. Effects of clozapine, thioridazine, risperidone and haloperidol on behavioral tests related to extrapyramidal motor function. Psychopharmacology (Berl). 1997;132(1):74-81.

12. Saller CF, Salama AI. D-1 and D-2 dopamine receptor blockade: interactive effects in vitro and in vivo. J Pharmacol Exp Ther. 1986;236(3):714-720.

13. Stoof JC, Kebabian JW. Opposing roles for D-1 and D-2 dopamine receptors in efflux of cyclic AMP from rat neostriatum. Nature. 1981;294(5839):366-368

14. Waddington JL. Spontaneous orofacial movements induced in rodents by very long-term neuroleptic drug administration: phenomenology, pathophysiology and putative relationship to tardive dyskinesia. Psychopharmacol (Berl). 1990;101(4):431-447.

15. Groenewegen HJ. The basal ganglia and motor control. Neural Plast. 2003;10(1-2):107-120.

16. Gurney K, Prescott TJ, Wickens JR, Redgrave P. Computational models of the basal ganglia: from robots to membranes. Trends Neurosci. 2004;27(8):453-459.

17. Weinberger DR, Berman KF, Zec RF. Physiologic dysfunction of dorsolateral prefrontal cortex in schizophrenia. I. Regional cerebral blood flow evidence. Arch Gen Psychiatry. 1986;43(2):114-124.

18. Lewis DA, Anderson SA. The functional architecture of the prefrontal cortex and schizophrenia. Psychol Med. 1995;25(5):887-894.

19. Manoach DS, Press DZ, Thangaraj V, et al. Schizophrenic subjects activate dorsolateral prefrontal cortex during a working memory task, as measured by fMRI. Biol Psychiatry. 1999;45(9):1128-1137.

20. Castner SA, Williams GV, Goldman-Rakic PS. Reversal of antipsychotic-induced working memory deficits by short-term dopamine $\mathrm{D}_{1}$ receptor stimulation. Science. 2000;287(5460):2020-2022. 
21. Creese I, Burt DR, Snyder SH. Dopamine receptor binding predicts clinical and pharmacological potencies of antischizophrenic drugs. Science. 1976;192(4238):481-483.

22. Glovinsky D, Kirch DG, Wyatt RJ. Early antipsychotic response to resumption of neuroleptics in drug-free chronic schizophrenic patients. Biol Psychiatry. 1992;31(9):968-970.

23. Carr VJ. Recovery from schizophrenia: a review of patterns of psychosis. Schizophr Bull. 1983;9(1):95-121.

24. Keck PE Jr, Cohen BM, Baldessarini RJ, McElroy SL. Time course of antipsychotic effects of neuroleptic drugs. Am J Psychiatry. 1989;146(10):1289-1292.

25. Stern RG, Kahn RS, Harvey PD, Amin F, Apter SH, Hirschowitz J. Early response to haloperidol treatment in chronic schizophrenia. Schizophr Res. 1993;10(2):165-171.

26. Sgambato V, Pages C, Rogard M, Besson MJ, Caboche J. Extracellular signal-regulated kinase (ERK) controls immediate early gene induction on corticostriatal stimulation. J Neurosci. 1998;18(21):8814-8825.

27. Gerfen CR, Miyachi S, Paletzki R, Brown P. D dopamine receptor supersensitivity in the dopamine-depleted striatum results from a switch in the regulation of ERK1/2/MAP kinase. $J$ Neurosci. 15 2002;22(12):5042-5054.

28. Goldman PS, Rosvold HE, Mishkin M. Evidence for behavioral impairment following prefrontal lobectomy in the infant monkey. J Comp Physiol Psychol. 1970;70(3):454-463.

29. Lopez-Tellez JF, Lopez-Aranda MF, Navarro-Lobato I, et al. Prefrontal inositol triphosphate is molecular correlate of working memory in nonhuman primates. J Neurso Sci. 2010;30(8):3067-3071.

30. Khan ZU, Gutierrez A, De Blas AL. Short and long form gamma 2 subunits of the GABAA/benzodiazepine receptors. J Neurochem. 1994;63(4):1466-1476.

31. Khan ZU, Mrzljak L, Gutierrez A, de la Calle A, Goldman-Rakic PS. Prominence of the dopamine $\mathrm{D}_{2}$ short isoform in dopaminergic pathways. Proc Natl Acad Sci U S A. 1998;95(13):7731-7736.

32. Khan ZU, Gutierrez A. Distribution of C-terminal splice variant of G alpha i2 in rat and monkey brain. Neuroscience. 2004;127(4): 833-843.

33. Khan ZU, Gutierrez A, Martin R, Penafiel A, Rivera A, de la Calle A. Dopamine $\mathrm{D}_{5}$ receptors of rat and human brain. Neuroscience. 2000;100(4):689-699.

34. Sharma T, Mockler D. The cognitive efficacy of atypical antipsychotics in schizophrenia. J Clin Psychopharmacol. 1998;18(2 Suppl 1):12S-19S.

35. Fuster JM. Memory in the cortex of the primate. Biol Res. 1995;28(1):59-72.

36. Fritts ME, Asbury ET, Horton JE, Isaac WL. Medial prefrontal lesion deficits involving or sparing the prelimbic area in the rat. Physiol Behav. 1998;64(3):373-380.
37. Seeman P, Lee T, Chau-Wong M, Wong K. Antipsychotic drug doses and neuroleptic/dopamine receptors. Nature. 1976;261(5562):717-719.

38. Luchins D. The dopamine hypothesis of schizophrenia. A critical analysis. Neuropsychobiol. 1975;1(6):365-378.

39. Meltzer HY, Stahl SM. The dopamine hypothesis of schizophrenia: a review. Schizophr Bull. 1976;2(1):19-76.

40. Sayed Y, Garrison JM. The dopamine hypothesis of schizophrenia and the antagonistic action of neuroleptic drugs-a review. Psychopharmacol Bull. 1983;19(2):283-288.

41. Snyder SH. The dopamine hypothesis of schizophrenia: focus on the dopamine receptor. Am J Psychiatry. 1976;133(2):197-202.

42. van Kammen DP. The dopamine hypothesis of schizophrenia revisited. Psychoneuroendocrinol. 1979;4(1):37-46.

43. Burt DR, Creese I, Snyder SH. Antischizophrenic drugs: chronic treatment elevates dopamine receptor binding in brain. Science. 1977;196(4287):326-328.

44. Seeman P. Brain dopamine receptors. Pharmacol Rev. 1980;32(3): 229-313.

45. O’Dell SJ, La Hoste GJ, Widmark CB, Shapiro RM, Potkin SG, Marshall JF. Chronic treatment with clozapine or haloperidol differentially regulates dopamine and serotonin receptors in rat brain. Synapse. 1990;6(2):146-153.

46. Jeste DV, Wyatt RJ. In search of treatment for tardive dyskinesia: review of the literature. Schizophr Bull. 1979;5(2):251-293.

47. Baldessarini RJ, Tarsy D. Dopamine and the pathophysiology of dyskinesias induced by antipsychotic drugs. Annu Rev Neurosci. 1980;3:23-41.

48. Tarazi FI, Florijn WJ, Creese I. Differential regulation of dopamine receptors after chronic typical and atypical antipsychotic drug treatment. Neuroscience. 1997;78(4):985-996.

49. Caligiuri MP, Lohr JB, Jeste DV. Parkinsonism in neurolepticnaive schizophrenic patients. Am J Psychiatry. 1993;150(9): 1343-1348.

50. Chatterjee A, Chakos M, Koreen A, et al. Prevalence and clinical correlates of extrapyramidal signs and spontaneous dyskinesia in never-medicated schizophrenic patients. Am J Psychiatry. 1995;152(12):1724-1729.

51. Miller DD, Andreasen NC, O'Leary DS, et al. Effect of antipsychotics on regional cerebral blood flow measured with positron emission tomography. Neuropsychopharmacology. 1997;17(4):230-240.

52. Corson PW, O'Leary DS, Miller DD, Andreasen NC. The effects of neuroleptic medications on basal ganglia blood flow in schizophreniform disorders: a comparison between the neuroleptic-naive and medicated states. Biol Psychiatry. 2002;52(9):855-862.
Open Access Animal Physiology

\section{Publish your work in this journal}

Open Access Animal Physiology is an international, peer-reviewed, open access journal publishing original research, reports, reviews and commentaries on all areas of animal physiology. The manuscript management system is completely online and includes a very

\section{Dovepress}

quick and fair peer-review system. Visit http://www.dovepress.com/ testimonials.php to read real quotes from published authors. 